\title{
Avaliação de risco de infecção por Salmonella sp. em consumidores de linguiça frescal de carne suína em Porto Alegre, RS*
}

\author{
LISANDRA MÜRMANN \\ Marisa Cardoso (Orientador - UFRGS) \\ Luis Gustavo Corbelinni (Co-orientador - UFRGS)
}

Banca: Verônica Schmidt (UFRGS), Eduardo César Tondo (UFRGS), Wladimir Padilha da Silva (UFPEL)

O isolamento de Salmonella enterica em suínos abatidos tem sido reportado no sul do Brasil, o que torna a carne suína uma fonte potencial de contaminação para os consumidores. Nesse contexto, o trabalho propôs estimar o risco da ocorrência de infecção alimentar pelo consumo de linguiça frescal suína, através da análise de dados de prevalência, quantificação, cinética de crescimento e destruição e de surtos alimentares que envolveram Salmonella no Rio Grande do Sul. Das 336 amostras de linguiça frescal de carne suína adquiridas no comércio, 24,4\% apresentaram Salmonella sp. com contagens variando entre 0,03 e 460 Número mais Provável (NMP).g-1 ${ }^{-1}$ com mediana de 0,23 NMP.g-1. Os sorovares mais prevalentes foram Brandenburg, Derby, Panama e Typhimurium. Em simulações de crescimento e destruição realizadas em caldo nutriente, isolados dos 12 sorovares encontrados no produto, apresentaram cinética de crescimento semelhante em temperatura ambiente. Até duas horas todos os sorotipos permaneceram em fase lag e, após, iniciou-se a fase exponencial. Em temperatura de refrigeração, todos os isolados mantiveram a contagem inicial até 30 dias. A destruição térmica em $60^{\circ} \mathrm{C}$ ocorreu após 20 minutos, em todos os ensaios. As mesmas simulações foram conduzidas em amostras do produto contaminadas artificialmente com Salmonella sp., não havendo alterações significativas nas quantidades de Salmonella em temperatura ambiente e de refrigeração durante todo o período de observação. Após a preparação em forno $\left(200^{\circ} \mathrm{C}\right)$, por 15 minutos, a população total inoculada foi destruída. Nos surtos ocorridos por Salmonella, os alimentos a base de ovos, maionese e frango predominaram. Os resultados obtidos na quantificação variaram de $<3 \mathrm{NMP}$ até $4,6 \times 10^{9} \cdot \mathrm{g}^{-1} \mathrm{desses}$ alimentos, com mediana de 4,6x10 ${ }^{6} \cdot \mathrm{g}^{-1} \cdot S$. Enteritidis foi o sorovar identificado em todos os surtos, apresentando um único perfil de macrorrestrição. Os dados obtidos foram utilizados para simular diferentes cenários no programa @ Risk. Considerando-se o costume da população estudada de ingerir este produto após tratamento térmico, o risco encontrado foi muito baixo $\left(6,12 \times 10^{-7}\right)$. Para uma pequena parte da população que costuma ingerir o produto sem qualquer tratamento térmico, em uma simulação realizada com 10.000 refeições, poderá haver 8,78 casos da doença, considerando a ingestão de uma única unidade. Em um perfil típico de preparação e consumo de linguiça frescal de carne suína pela população de Porto Alegre, ou seja, como acompanhamento de churrasco, após tratamento térmico mínimo de 15 minutos, calculou-se a probabilidade de ocorrência de doença. Dentre os 3.354.716,98 churrascos estimados consumidos mensalmente em Porto Alegre, o resultado do modelo indicou um mínimo de 0,01, média de 2,05 e máximo de 11,08 casos de doença por mês. Esse cenário infere que a linguiça frescal de carne suína pode estar causando um baixo número de casos isolados em Porto Alegre, os quais podem estar sendo subnotificados.

Descritores: Análise de risco, Salmonella, linguiça frescal de carne suína

Apresentada: 26 fevereiro 2008

\footnotetext{
*Tese de Doutorado n. 91 (Especialidade: Bacteriologia). 128f. Programa de Pós-Graduação em Ciências Veterinárias [www.ufrgs.br/ppgcv]. Faculdade de Veterinária, Universidade Federal do Rio Grande do Sul (UFRGS), Porto Alegre/RS. CORRESPONDÊNCIA: L.M. Mürmann [lismurmann@yahoo.com.br].
} 


\title{
Risk assessment of Salmonella infection in consumers of pork sausage in Porto Alegre, RS**
}

\author{
LISANDRA MÜRMANN
}

\author{
Marisa Cardoso (Adviser-UfRGS)
}

Luis Gustavo Corbellini (Co-Adviser-UFRGS)

Committee: Schmidt (UFRGS), Eduardo César Tondo (UFRGS), Wladimir Padilha da Silva (UFPEL)

In Southern Brazil, a high prevalence of Salmonella isolation has been reported in slaughter pigs, indicating that pork may represent a hazard to the consumers. In this sense, this study aimed to conduct a risk analysis of the consumption of pork sausage in Southern Brazil. For this purpose, Salmonella prevalence on pork sausages collected at retail level was estimated, growth and death curves for representative porcine Salmonella strains were constructed, the consumption patterns of pork sausages by the population were investigated, and foods involved in salmonellosis outbreaks were analysed. From a total of 336 samples of fresh pork sausage examined, Salmonella enterica was detected in $82(24.4 \%)$ of the samples, with a Most Probable Number count ranging from 0.03 (MPN). $\mathrm{g}^{-1}$ to $460 \mathrm{MPN} . \mathrm{g}^{-1}$, and a median of $0.23 \mathrm{MPN}$. $\mathrm{g}^{-1}$. Strains belonging to serovars Brandenburg, Panama, Derby and Typhimurium were the most prevalent. Growth and death curves of 12 strains representing Salmonella serovars isolated in this study were similar in assays conducted in nutrient broth. At room temperature, all Salmonella serovars started the exponential phase after a two hours period of lag phase. Under refrigeration, all isolates mantained the initial population counts up to 30 days. The heat destruction was observed after 20 minutes in all assays. Similar assays conducted in fresh pork sausages inoculated with Salmonella demonstrated that no growth of Salmonella sp. could be detected at room temperature and under refrigeration troughout the observation period. After cooking in the oven $\left(200^{\circ} \mathrm{C}\right)$ for 15 minutes the inoculated Salmonella population was completely destroyed. Foods containing eggs, mayonnaise or chicken were the most implicated in outbreaks investigated in Rio Grande do Sul. Salmonella counts variaded from $<3$ MPN to $4.6 \times 10^{9} \cdot \mathrm{g}^{-1}$ of foods involved in these outbreaks, with a median value of $4.6 \times 10^{6} \cdot \mathrm{g}^{-1}$. All strains were identified as S. Enteritidis, and presented a unique macrorestriction profile, demonstrating the predominance of one clonal group in foods involved in the salmonellosis outbreaks. Data obtained in the conducted assays were used to simulate different cenarios, using the @Risk software. Considering that the population usually consums pork sausage after termic treatment (roasting), the estimated risk was very low $\left(6.12 \times 10^{-7}\right)$. Another simulation, conducted for the low percentage of the population $(3 \%)$ that declared to consum raw pork sausage, indicated that for 10,000 meal consumption events of one sausage, the probability is 8.78 disease cases. Finally, considering the typical consumption pattern of pork sausage by the population of Porto Alegre city (roasted for at least 15 minutes during a barbecue called "churrasco") the number of disease cases was simulated. Among 3,354,716.98 "churrascos" prepared monthly in Porto Alegre city, the model indicated a probability of a minimum of 0.01 cases, a media of 2.05 and a maximum of 11.08 disease cases occurring each month. Results of risk assessment show that fresh pork sausage may have been a cause of few undernotificated individual salmonellosis cases in Porto Alegre city.

Key words: Pork, risk assessment, fresh pork sausage.

Presented: 26 February 2008

\footnotetext{
** Doctoral Dissertation \# 91 (Field- Bacteriology). 128p. Graduate Program in Veterinary Sciences [www.ufrgs.br/ppgcv]. Faculdade de Veterinária, Universidade Federal do Rio Grande do Sul(UFRGS), Porto Alegre/Brazil. CORRESPONDENCE: L.M. Mürmann [lismurmann@yahoo.com.br].
} 